\title{
FARMERS' PERCEPTIONS TOWARDS SELECTED ENVIRONMENTAL VALUES: A REGIONAL STUDY FROM POLAND
}

\author{
Alina Syp ${ }^{1}$ Dr.hab., Assoc. Prof.; Dariusz Osuch ${ }^{2}$ Dr. \\ ${ }^{1}$ Department of Bioeconomy and Systems Analysis, Institute of Soil Science and Plant Cultivation - Sate \\ Research Institute (IUNG-PIB); ${ }^{2}$ Agricultural Accountancy Department, Institute of Agricultural and Food \\ Economics - National Research Institute
}

\begin{abstract}
Agricultural intensification has a negative impact on environment resulting in, among others, decrease in biodiversity, soil erosion, deforestation and forest degradation, increase of greenhouse gas emissions. In order to keep the balance between intensification and extensification of food production, in the frame of Agricultural Policy (CAP), the Agri-environmental schemes (AES) were introduced. Since 1992 the importance of environmental aspect has grown, which resulted in reforms of AES and a significant increase in expenses for these purposes. However, many studies present the negative environmental impact of agricultural practices as an ongoing problem. It is due to not efficiently implemented AES by farmers. The better knowledge of environmental perceptions by farmers can be a key to the further policy development. We investigate the view of crop fields and mixed farmers towards environmental awareness in Poland, in the FADN region of Mazowsze and Podlasie. In 2017, we conducted a survey on 189 farms, of which 93 participated in AES since 2010. Our results indicate that all surveyed farmers were characterized by high environmental awareness. There were No major differences between AES and non-AES respondents in the perception of environmental threats. The obtained results do not confirm colloquially adopted opinion that farmers participating in AES are more aware of environmental pressure due to the fact that they follow AES regulations. Field corps and mixed farmers from AES and non-AES groups emphasized that there is a need to raise ecological awareness in order to improve the state of environment.
\end{abstract}

Key words: agri-environmental schemes, environment, field crop farms, mixed farms. JEL code: Q18.

\section{Introduction}

Intensification was one of the factors influencing modernization of agriculture, however, it had the side-effect of growing influence on the environment. Therefore, to resolve this pressure, since 1992 the Agri-environment schemes (AES) have been implemented in all European Union (EU) Member States. AES (now agri-environmental-climate-schemes) are one of the main tools used by the EU to achieve environmental sustainability (EC, 2017). Farmers who voluntary participate in AES receive financial support for adoption of environmentally-friendly management practices. However, a number of studies point out the implementation of agri-environmental measures (AEM) are not always as efficient as planned and expected (Hammes et al., 2016). As farmers play a major role in AES, the better knowledge about their perception towards environmental values can play crucial role in the process of decision-making. This approach is based on the assumption that farmers constitute a very heterogeneous community, think differently and have diverse attitudes, therefore, need to be addressed accordingly. The research presented in this paper makes a contribution to the existing literature on the development of AES schemes.

The aim of the present study was to assess how different farmers perceive environmental values.

The analysis was based on questionnaire survey from a sample of Polish farms from the Region of Mazowsze and Podlasie. The region includes the following voivodships: mazowieckie, podlaskie, lubelskie and lodzkie. This area has been chosen for analysis because the utilized agricultural area (UAA) of the region represents $37.2 \%$ of the country's UAA (CSO, 2017). In the period 2010-2015, the share of farmers who applied for ASE payments amounted to $35 \%$ of all applicants, and the requested amount represented $25 \%$ of the national quota (ARMIR, 2015). To achieve a representative picture of the main production systems of the region, the selection of the farms was 
based on the Farm Data Network (FADN) data for the period of 2010-2015. The research covered only those farms that were in the FADN system throughout the whole period taken into account. The analysis was performed for two groups of farms. First included farms participating in AES and second - not committed to AES (non AES). In each group the two types of farms were selected, based on EU standard classification of type of farming (TF 8) (EC, 2008). The criterion for classification of the agricultural holdings is determined by the relative contribution of the standard output of different characteristics of the holding to the total standard output. Based on these, the analyses were performed for field crops (TF1) and mixed (TF 8) farms. The sample of holdings from FADN database which participated in AES consisted of 147 farms including 75 mixed and 72 field crops. The same number of non AES holdings located as close as possible to AES farms were selected. In total, 294 farms were chosen to participate in a survey in the region of Mazowsze and Podlasie. The questionnaire was designed by authors, based on literature review. Next, it was presented and discussed with farmers and agricultural advisors, then piloted on a small number of selected farmers. Since the holdings were selected from FADN database, socio-demographic variable were not included in the questionnaire. This caused that the questionnaire was shorter and reduced the time required from respondents. The survey included four main sections. The first four sections contained questions related to perceptions on environmental issues. The respondents were asked to answer 'Yes', 'No' or 'I do not have an opinion'. The last part of the survey included questions measuring farmers' attitude to environmental' regulations. The perceptions were assessed on five-point Likert scale, where $1=$ strongly disagree and $5=$ strongly agree, with three reverse score items. The survey was carried out in analysed area on the farmers' holdings using a uniform questionnaire in face to face interview performed by advisors from Agricultural Extension Services. The interviews were conducted in 2017. The obtained data were processed using descriptive statistics.

\section{Research results and discussion}

In total, 189 farmers returned fully completed questionnaires, thus the response rate range from 60 to $67 \%$. The detail distribution of responses according to the typology of agricultural holdings is presented in Table 1. Because of commitment of agricultural advisors, the response rate was higher than received by other researchers using different channel distributions. Case et al. (2017) performed survey by post and recorded $28 \%$ of response rate. Barnes et al. (2012) conducted telephone survey and obtained a response rate of $33 \%$ whereas Woods et al. (2017) using an online farmer panel $-36 \%$. Table 2 presents descriptive statistics of survey field crops and mixed farms. In both types of farming the economic size of AES farms was slightly lower than non-AES. However, the family farm incomes of AES farms were higher despite the fact that total outputs were lower compared to non-AES farms. It was due to higher subsidies received by AES farms. In AES farms the labour inputs were lower compared to non-AES farms. The AES filed crop farms were characterized by higher UAA, rented UAA and family farm income compared to non-AES field crop farms. But total assets of those AES farms were lower than of non-AES ones. For the question "Do you think that you have an impact on the environment?" the answer 'yes' was declared by a higher number of non-AES than AES respondents (Table 3). However, more AES than non-AES mixed farmers agreed that intensive agriculture has a negative impact on the environment (Table 4). The views of field crop farmers were opposite compared to mixed farmers. The obtained responses show that mixed farmers are more aware of destructive influence of agriculture on surroundings than field crop farmers. In the opinion of all farmers, the greatest threats to the environment are application 
of high doses of pesticides and fertilizers (Table 5). Intensification of crop production and high concentration of livestock were perceived as a lower danger to environment. On the basis of conducted questionnaire survey we can state that environmental awareness is higher among both types AES than non-AES farmers. Significantly, higher number of non-AES farmers does not see any threat to environment from improper waste management, decline of biodiversity and soil erosion. In addition, a large number of non AES respondents do not have opinion on these issues. Our outcomes are in agreement with the research results obtained by Mroczek et al. (2013). Regarding action which should be taken to improve the state of environment, the findings showed that for majority of respondents the financial incentives are the most important (Table 6). In the second place was the answer - to raise ecological awareness. The \% shares of farmers who see the need to raise knowledge on this topic are: 84 and $88 \%$, respectively for AES and non-AES field crops. In mixed farms more AES ( $82 \%)$ than non-AES ( $77 \%$ ) see the necessity for increased ecological awareness. A lower percentage of farmers stated that control and punishment for environmental pollution may improve the state of environment. The financial invectives have been indicated as the most important factor in AES and non-AES farms in studies of Mroczek et al. (2013). However, the second one was the control and punishment with scores 36 and $20 \%$, respectively for AES and non-AES respondents. Only $4 \%$ of AES farmers and $10 \%$ of non-AES farmers indicated the needs of raising of ecological awareness. In our opinion the difference between the answers may have resulted from, inter alia, various sampling and testing periods. Mroczek et al. (2013) performed their survey in 2012 whereas our survey was carried out in 2017. We can assume that up to this period the farmers' knowledge about environment and AES schemes increased. Secondly, Mroczek et al. (2013) did studies on sample farms selected in Lezajsk county whereas in our research we applied a targeted selection based on FADN database. A belief that participation in AES schemes have increased labour input at farm is a commonly circulated opinion. This statement was confirmed by AES respondents in our survey (Tables 7 and 8 ). However, the descriptive statistics calculated for this sample indicate the contrary (Table 2). The labour inputs were higher in field and mixed non-AES farms. This is in agreement with non-AES farmers' opinions from the questionnaire. Over $50 \%$ of respondents in all questioned groups agreed that implementation of environmental regulations lowers farm income (Tables 7 and 8). Table 2 confirms this statement. In AES field crop farms the total output was by $18 \%$ higher than in non-AES farms. But family farm income of non-AES farms was by $21 \%$ lower compared to AES farms (Table 2). In the mixed farms the differences were as follow: 17 and $5 \%$, respectively for total output and family farm income. In AES non-field crop samples, the value of total assets was by $10 \%$ higher compared to AES farms but index of assets productivity measure as a ratio of total output to total assets was only by $1 \%$ higher. Presented data show how much AES subsidies influence family farm income in the field crop farms. Results for mixed farms are slightly different. The average value of total assets of non-AES mixed farms was by $5 \%$ lower than AES farms, but index of assets productivity of these farms was by $3 \%$ higher. This shows that non-AES mixed farms were better managed. The need for implementation of environmental regulations as a positive factor for the future of agriculture was declared by more mixed than crop filed farmers (Table 7). The results obtained indicate higher environmental awareness among mixed farm respondents. 
Number of farmers who completed survey and response rate in \%

\begin{tabular}{|l|c|c|c|c|c|}
\hline No. & $\begin{array}{c}\text { Farm } \\
\text { type }\end{array}$ & $\begin{array}{c}\text { Number of responses } \\
\text { from farmers } \\
\text { participating in AES }\end{array}$ & $\begin{array}{c}\text { Response } \\
\text { rate ( \%) }\end{array}$ & $\begin{array}{c}\text { Number of responses } \\
\text { from farmers not } \\
\text { participating in AES }\end{array}$ & $\begin{array}{c}\text { Response } \\
\text { rate ( \%) }\end{array}$ \\
\hline 1. & $\begin{array}{c}\text { Field } \\
\text { Crops }\end{array}$ & 43 & 60 & 48 & 67 \\
\hline 2. & Mixed & 50 & 67 & 48 & 64 \\
\hline 3. & Total & 93 & 63 & 96 & 65 \\
\hline
\end{tabular}

Source: authors' calculations based on the survey

Descriptive statistics of survey field crops and mixed farms in 2015

\begin{tabular}{|l|c|c|c|c|c|}
\hline \multirow{2}{*}{ No. } & \multirow{2}{*}{ General information } & \multicolumn{4}{|c|}{ Type of farms } \\
\cline { 3 - 6 } & & \multicolumn{2}{|c|}{ Field crops } & \multicolumn{2}{c|}{ Mixed } \\
\cline { 3 - 6 } & & AES & Non AES & AES & Non AES \\
\hline 1. & Number of farms (SYS03) & 43 & 48 & 50 & 48 \\
\hline $\mathbf{2 .}$ & Economic size (SE005)(EUR) & 29008 & 32806 & 24381 & 24724 \\
\hline 3. & UAA (SE 025) (ha) & 42.4 & 40.6 & 23.2 & 20.7 \\
\hline 4. & Rented UAA (SE030)(ha) & 13.3 & 12.1 & 5.0 & 6.4 \\
\hline $\mathbf{5 .}$ & No animals per farm (SE080)(LU) & 2.1 & 1.5 & 15.0 & 17.0 \\
\hline $\mathbf{6 .}$ & Labour input (SE010)(AWU) & 1.35 & 1.53 & 1.69 & 1.77 \\
\hline $\mathbf{7}$ & Total output ((SE131)(PLN) & 142762 & 167750 & 101464 & 118469 \\
\hline $\mathbf{8 .}$ & Family farm income (SE 420)(PLN) & 78980 & 65311 & 41052 & 39212 \\
\hline $\mathbf{9 .}$ & Total assets (SE 436)(PLN) & 996894 & 1093642 & 675505 & 643075 \\
\hline
\end{tabular}

Notes: PLN - Polish currency. UAA - Utilised Agricultural Area. AWU - Annual Work Unit, LU - livestock unit

Source: authors' calculations based on the FADN data

Responses given to question "Do you think that you have an impact on the environment?" (\%)

\begin{tabular}{|l|c|c|c|c|}
\hline No. & Farm types & Yes & No & I have No opinion \\
\hline 1. & AES Field crops & 86 & 2 & 12 \\
\hline 2. & Non AES Field crops & 90 & 8 & 2 \\
\hline 3. & AES Mixed & 74 & 8 & 18 \\
\hline 4. & Non AES Mixed & 79 & 2 & 19 \\
\hline
\end{tabular}

Source: authors' calculations based on the survey

Responses given to question „Do you think that intensive agriculture has a negative impact on the environment?" ( \%)

\begin{tabular}{|l|c|c|c|c|}
\hline No. & Farm types & Yes & No & I have No opinion \\
\hline 1. & AES Field crops & 81 & 5 & 14 \\
\hline 2. & Non AES Field crops & 86 & 6 & 8 \\
\hline 3. & AES Mixed & 86 & 6 & 8 \\
\hline 4. & Non AES Mixed & 83 & 6 & 11 \\
\hline
\end{tabular}

Source: authors' calculations based on the survey 
Responses given to question „What are the highest threats to the environment?" ( \%)

\begin{tabular}{|c|c|c|c|c|c|c|c|c|c|c|c|c|c|}
\hline \multirow[b]{2}{*}{$\begin{array}{c}\text { No } \\
\text { - }\end{array}$} & \multirow[b]{2}{*}{ Items } & \multicolumn{3}{|c|}{ AES Field crops } & \multicolumn{3}{|c|}{$\begin{array}{c}\text { Non AES Field } \\
\text { crops }\end{array}$} & \multicolumn{3}{|c|}{ AES Mixed } & \multicolumn{3}{|c|}{ Non AES Mixed } \\
\hline & & $\begin{array}{c}\text { Ye } \\
\text { s }\end{array}$ & $\begin{array}{l}\mathbf{N} \\
\mathbf{O}\end{array}$ & $\begin{array}{c}\text { I have } \\
\text { no } \\
\text { opinio } \\
\text { n }\end{array}$ & $\begin{array}{c}\text { Ye } \\
\text { s }\end{array}$ & $\begin{array}{l}\mathbf{N} \\
\mathbf{O}\end{array}$ & $\begin{array}{c}\text { I have } \\
\text { no } \\
\text { opinio } \\
\text { n }\end{array}$ & $\begin{array}{c}\text { Ye } \\
\text { s }\end{array}$ & $\begin{array}{l}\mathbf{N} \\
\mathbf{O}\end{array}$ & $\begin{array}{c}\text { I have } \\
\text { no } \\
\text { opinio } \\
\text { n }\end{array}$ & $\begin{array}{c}\text { Ye } \\
\text { s }\end{array}$ & $\begin{array}{l}\mathbf{N} \\
\mathbf{O}\end{array}$ & $\begin{array}{c}\text { I have } \\
\text { no } \\
\text { opinio } \\
\text { n }\end{array}$ \\
\hline 1. & $\begin{array}{l}\text { Intensificatio } \\
\mathrm{n} \text { of crop } \\
\text { production }\end{array}$ & 65 & 14 & 21 & 63 & 13 & 25 & 70 & 20 & 10 & 44 & 19 & 38 \\
\hline 2. & $\begin{array}{c}\text { High } \\
\text { concentratio } \\
\mathrm{n} \text { of livestock }\end{array}$ & 74 & 7 & 19 & 79 & 2 & 19 & 78 & 8 & 14 & 81 & 6 & 13 \\
\hline 3. & $\begin{array}{c}\text { High } \\
\text { fertilization } \\
\text { doses }\end{array}$ & 88 & 5 & 7 & 79 & 10 & 10 & 88 & 6 & 6 & 81 & 8 & 10 \\
\hline 4. & $\begin{array}{c}\text { High } \\
\text { pesticides } \\
\text { doses }\end{array}$ & 88 & 2 & 9 & 92 & 0 & 8 & 92 & 4 & 4 & 94 & 2 & 4 \\
\hline 5. & Soil erosion & 63 & 12 & 26 & 50 & 10 & 40 & 76 & 6 & 18 & 38 & 4 & 58 \\
\hline 6. & $\begin{array}{c}\text { Waste } \\
\text { management }\end{array}$ & 74 & 12 & 14 & 58 & 13 & 29 & 74 & 14 & 12 & 63 & 2 & 35 \\
\hline 7. & $\begin{array}{c}\text { Decline of } \\
\text { biodiversity }\end{array}$ & 74 & 9 & 16 & 35 & 15 & 50 & 80 & 6 & 14 & 42 & 8 & 50 \\
\hline 8. & $\begin{array}{l}\text { Emissions of } \\
\text { pollutants to } \\
\text { the } \\
\text { atmosphere }\end{array}$ & 81 & 12 & 7 & 73 & 10 & 17 & 82 & 6 & 12 & 75 & 2 & 23 \\
\hline
\end{tabular}

Source: authors' calculations based on the survey

Responses given to question „What should be done to improve the state of environment?" ( \%)

\begin{tabular}{|c|c|c|c|c|c|c|c|c|c|c|c|c|c|}
\hline \multirow[b]{2}{*}{ No } & \multirow[b]{2}{*}{ Items } & \multicolumn{3}{|c|}{ AES Field crops } & \multicolumn{3}{|c|}{$\begin{array}{c}\text { Non AES Field } \\
\text { crops }\end{array}$} & \multicolumn{3}{|c|}{ AES Mixed } & \multicolumn{3}{|c|}{ Non AES Mixed } \\
\hline & & $\begin{array}{c}\text { Ye } \\
\text { s }\end{array}$ & $\begin{array}{l}\mathbf{N} \\
\mathbf{O}\end{array}$ & $\begin{array}{c}\text { I have } \\
\text { no } \\
\text { opinio } \\
\text { n }\end{array}$ & $\begin{array}{c}\text { Ye } \\
\text { s }\end{array}$ & $\begin{array}{l}\mathbf{N} \\
\mathbf{O}\end{array}$ & $\begin{array}{c}\text { I have } \\
\text { no } \\
\text { opinio } \\
\text { n }\end{array}$ & $\begin{array}{c}\text { Ye } \\
\text { s }\end{array}$ & $\begin{array}{l}\mathbf{N} \\
\mathbf{O}\end{array}$ & $\begin{array}{c}\text { I have } \\
\text { no } \\
\text { opinio } \\
\text { n }\end{array}$ & $\begin{array}{c}\text { Ye } \\
\text { s }\end{array}$ & $\begin{array}{l}\mathbf{N} \\
\mathbf{0}\end{array}$ & $\begin{array}{c}\text { I have } \\
\text { no } \\
\text { opinio } \\
\text { n }\end{array}$ \\
\hline 1. & $\begin{array}{c}\text { Raise } \\
\text { ecological } \\
\text { awareness }\end{array}$ & 84 & 5 & 12 & 88 & 0 & 13 & 82 & 2 & 16 & 77 & 6 & 17 \\
\hline 2. & $\begin{array}{c}\text { Apply } \\
\text { financial } \\
\text { incentives }\end{array}$ & 93 & 5 & 2 & 81 & 6 & 13 & 88 & 6 & 6 & 85 & 4 & 10 \\
\hline 3. & $\begin{array}{c}\text { Control and } \\
\text { punishment } \\
\text { for } \\
\text { environment } \\
\text { al pollution }\end{array}$ & 65 & 16 & 19 & 50 & 10 & 40 & 64 & 18 & 18 & 48 & 17 & 35 \\
\hline
\end{tabular}

Source: authors' calculations based on the survey 


\section{Responses given by field crops farmers on their attitudes towards environmental regulations (\%)}

\begin{tabular}{|c|c|c|c|c|c|c|c|}
\hline No. & Items & $\begin{array}{l}\text { Strongly } \\
\text { disagree }\end{array}$ & Disagree & Neutral & Agree & $\begin{array}{l}\text { Strongly } \\
\text { agree }\end{array}$ & $\begin{array}{l}\text { Mean } \\
\text { (St Dev) }\end{array}$ \\
\hline & \multicolumn{7}{|c|}{ AES Field Crops } \\
\hline 1. & $\begin{array}{l}\text { Environmental regulations increase } \\
\text { the farmer's work input }\end{array}$ & 2.3 & 9.3 & 11.6 & 46.5 & 30.2 & $\begin{array}{l}3.93 \\
(1.0)\end{array}$ \\
\hline 2. & $\begin{array}{l}\text { Implementation of environmental } \\
\text { regulations lowers farm income }\end{array}$ & 2.3 & 16.3 & 25.6 & 41.9 & 14.0 & $\begin{array}{l}3.49 \\
(1.0)\end{array}$ \\
\hline \multirow[t]{2}{*}{3.} & $\begin{array}{l}\text { Environmental regulations are good } \\
\text { for the future of agriculture }\end{array}$ & 0.0 & 7.0 & 30.2 & 32.6 & 30.2 & $\begin{array}{l}3.86 \\
(0.93)\end{array}$ \\
\hline & \multicolumn{7}{|c|}{ Non AES Field Crops } \\
\hline 4. & $\begin{array}{l}\text { Environmental regulations increase } \\
\text { the farmer's work input }\end{array}$ & 6.3 & 14.6 & 14.6 & 50.0 & 14.6 & $\begin{array}{l}3.52 \\
(1.10)\end{array}$ \\
\hline 5. & $\begin{array}{l}\text { Implementation of environmental } \\
\text { regulations lowers farm income }\end{array}$ & 4.2 & 12.5 & 25.0 & 43.8 & 14.6 & $\begin{array}{c}3.52 \\
(1.02)\end{array}$ \\
\hline 6. & $\begin{array}{l}\text { Environmental regulations are good } \\
\text { for the future of agriculture }\end{array}$ & 0.0 & 10.4 & 25.0 & 35.4 & 29.2 & $\begin{array}{l}3.83 \\
(0.96)\end{array}$ \\
\hline
\end{tabular}

Source: authors' calculations based on the survey

Responses given by mixed farmers on their attitudes towards environmental regulations ( \%)

\begin{tabular}{|c|c|c|c|c|c|c|c|}
\hline \multirow{2}{*}{ No. } & Items & $\begin{array}{l}\text { Strongly } \\
\text { disagree }\end{array}$ & Disagree & Neutral & Agree & $\begin{array}{l}\text { Strongly } \\
\text { agree }\end{array}$ & $\begin{array}{l}\text { Mean } \\
\text { (St Dev) }\end{array}$ \\
\hline & \multicolumn{7}{|c|}{ AES Mixed } \\
\hline 1. & $\begin{array}{l}\text { Environmental regulations increase } \\
\text { the farmer's work input }\end{array}$ & 2.0 & 12.0 & 10.0 & 44.0 & 32.0 & $\begin{array}{c}3.92 \\
(1.04)\end{array}$ \\
\hline 2. & $\begin{array}{l}\text { Implementation of environmental } \\
\text { regulations lowers farm income }\end{array}$ & 0.0 & 24.0 & 20.0 & 48.0 & 8.0 & $\begin{array}{l}3.40 \\
(0.94)\end{array}$ \\
\hline \multirow[t]{2}{*}{3.} & $\begin{array}{l}\text { Environmental regulations are good } \\
\text { for the future of agriculture }\end{array}$ & 2.0 & 8.0 & 14.0 & 50.0 & 26.0 & $\begin{array}{l}3.90 \\
(0.94)\end{array}$ \\
\hline & \multicolumn{7}{|c|}{ Non AES F Mixed } \\
\hline 4. & $\begin{array}{l}\text { Environmental regulations increase } \\
\text { the farmer's work input }\end{array}$ & 4.2 & 12.5 & 18.8 & 41.7 & 22.9 & $\begin{array}{l}3.67 \\
(1.09)\end{array}$ \\
\hline 5. & $\begin{array}{l}\text { Implementation of environmental } \\
\text { regulations lowers farm income }\end{array}$ & 2.1 & 10.4 & 33.3 & 37.5 & 16.7 & $\begin{array}{l}3.56 \\
(0.96)\end{array}$ \\
\hline 6. & $\begin{array}{l}\text { Environmental regulations are good } \\
\quad \text { for the future of agriculture }\end{array}$ & 2.1 & 10.4 & 16.7 & 47.9 & 22.9 & $\begin{array}{c}3.79 \\
(0.98)\end{array}$ \\
\hline
\end{tabular}

Source: authors' calculations based on the survey

\section{Conclusions, proposals, recommendations}

1) All surveyed farmers were characterized by high environmental awareness. It might result from the fact that the farmers' selection was based on FADN database. It is assumed that farmers who participate in this system have better knowledge about agricultural production.

2) There were No major differences between AES and non-AES respondents in the perception of environmental threats. The obtained results do not confirm the colloquially adopted opinion that 
farmers participating in AES are more aware of environmental pressure due to the fact that they follow AES regulations.

3) Field corps and mixed farmers from AES and non-AES groups emphasized that there is a need to raise farmers' ecological awareness in order to improve the state of environment. Therefore, the efforts to expand environmental awareness should be more intensive.

4) Strengthening the ecological culture among farmers is one of the necessary conditions for building a sustainable rural development. The role of AES schemes in nature conservation will grow along with the inputs for their realization and their implementation is important mainly for social reasons.

5) This paper contributes to the literature on the development of AES schemes.

\section{Acknowledgements}

The studies have been supported by the IUNG-PIB Multiannual Programme (Task 1.7), supporting Ministry of Agriculture and Rural Development actions for protection and rational use of agricultural production space in Poland and ensuring the quality of plant raw materials.

\section{Bibliography}

1. ARiMR (2015). Informacja o liczbie złozonych wnioskow, liczbie i kwocie wydanych decyzji w ramach Dzialania "Program rolnosrodowiskowy PROW 2007-2013" Kampania 2015. (Information on the number of applications submitted, the number and amount of decisions issued as part of the "RDP 2007-2013 agrienvironmental program". Campaign 2015.). Retrieved:

https://www.arimr.gov.pl/fileadmin/pliki/wdrazane_programy_sprawozdania/PROW_2007-

2013/Rolnosrodowiskowe_/28122015_Rolnosrodowiskowe_7-13.pdf. Access: 18.01.2019

2. Barnes, A.P., Toma, L. (2011). A typology of dairy farmer perceptions towards climate change. Climatic Change No. 112, pp. 507-522.

3. Case, S.D.C., Oelofse, M., Hou, Y., Oenema, O., Jensen, L.S. (2017). Farmer perceptions and use of organic waste products as fertilisers - A survey study of potential benefits and barriers. Agricultural Systems. No.151, pp. 84-95.

4. CSO (2017). Statistical Yearbook of the Regions - Poland. Warszawa.

5. EC (2009). Commission Regulation (EC) 1291/2009 of 18 December 2009 Concerning the Selection of Returning Holdings for the Purpose of Determining Incomes of Agricultural Holdings. Official Journal of the European Commission. Commission Regulation (EC) No 1291/2009 of 18 December 2009 concerning the selection of returning holdings for the purpose of determining incomes of agricultural holdings. No. 347, pp. 14-21.

6. EC (2017). Science for Environment Policy. Agri-environmental schemes: how to enhance the agricultureenvironment relationship. Thematic Issue 57. Issue produced for the European Commission DG Environment by the Science Communication Unit. UWE. Bristol. Retrieved: http://ec.europa.eu/science-environmentpolicy. Access: 18.01.2019

7. Hammes, V., Eggers, M., Isselstein, J., Kayser, M. (2016). The attitude of grassland farmers towards nature conservation and agri-environment measures - A survey-based analysis. Land Use Policy. No. 59, pp. 528535.

8. Mroczek, J. R., Kostecka, J., Korczynska, M. (2013). Ocena roli programu rolnosrodowiskowego w postrzeganiu przez rolnikow wybranych aspektow problematyki srodowiskowej.(Farmers' perceptions of selected environmental aspects of the agri-environmental program). Inzynieria ekologiczna. No 34, pp. 189197.

9. Woods, B.A., Nielsen, H.Ø., Pedersen, A.B., Kristofersson, D. (2017). Farmers' perceptions of climate change and their likely responses in Danish agriculture. Land Use Policy. No. 65, pp. 109-120. 